http://dx.doi.org/10.12775/szhf.2020.001

\title{
Kompendium „Teologii Platońskiej”. Wznoszenie się od substancji cielesnej do niecielesnej, tj. do dusz, aniołów i Boga
}

\section{Marsilius Ficinus pozdrawia swoich braci w filozofii}

Jako że substancja to podłoże wszelkiej przypadłości, jest w pewnym porządku natury wcześniejsza od przypadłości, a ponieważ jest wcześniejsza i nie brakuje jej mocy formy, może gdzieś trwać bez przypadłości; bez przypadłości, mówię, zwłaszcza cielesnej, która - podpadając pod ogólną zasadę [metafizyczną] - przynosi nie tyle zysk, ile szkodę. Bez wątpienia, jeśli substancja może trwać bez przypadłości cielesnej, im będzie prawdziwsza ze względu na oczyszczenie [jej z nich], tym większą moc będzie miała ze względu na samą prostotę i jedność niepodzielnej natury. Pewna substancja jest zatem w akcie bez podziału ilościowego i zmieszania z jakością cielesną, aby owa moc tak rozumna i tak dobra nie zawsze na próżno była w uniwersum, [i aby] natura,

Praca powstała w wyniku realizacji projektu badawczego o nr 2018/29/B/HS1/00462, finansowanego ze środków Narodowego Centrum Nauki. 
która jest uważana za prawdziwszą i silniejszą niż jakakolwiek substancja cielesna, nie była albo całkowicie fałszywa, albo zupełnie pozbawiona siły.

Pierwszym stopniem substancji niecielesnej jest pewne życie, tj. dusza ${ }^{1}$. Wydaje się zatem, że tym samym jest owa niecielesna substancja i pewne życie, zważywszy, że życiu właściwa jest pewna siła, niezmiernie zadziwiająca, do przenikania, jednoczenia, poruszania ciała. Taką siłę ma przede wszystkim substancja całkowicie niecielesna. Pewne życia tego rodzaju już istnieją w porządku rzeczy. W większym stopniu bowiem żyjące ciało zależy od złączonego ze sobą życia niż życie od ciała. Z niego wszak ciało jest formowane, podtrzymywane, zarządzane i poruszane. Stąd, skoro poniżej takiego połączenia ciała i życia znajdują się pewne ciała, jak kamienie i metale, i inne [rzeczy] tego rodzaju, które mogą trwać bez życia, to o wiele bardziej i być może nawet więcej żyć istnieje, które mogą trwać bez wsparcia jakiegokolwiek ciała, i tymi po części są [ludzkie] dusze rozumne, po części aniołowie. Ponad duszami są aniołowie. Czy rzeczywiście prawdą jest to, iż z konieczności ponad ciałami i duszami są aniołowie? Bezwzględnie jest to konieczne. Istotnie wydaje się, że natura samego umysłu, na ile jest umysłem, jest taka, iż raczej żyje oddzielnie od ciała niż w ciele. Pojmuje bowiem poprzez pewne abstrahowanie form od wszystkich doznań ciał i na ile znaczniej od nich abstrahuje, na tyle jaśniej rozróżnia, efektywniej działa i szczęśliwiej żyje, jakby ta dyspozycja była w najwyższym stopniu naturalna. Połączenie umysłu z ciałem zaś nie jest - być może - niczym innym niż wyraźnym odłączeniem go od jego źródła. Natomiast to, co jest bardziej naturalne, ujawnia się w najwyższym stopniu w samym porządku rzeczy, więc ponad tymi umysłami, które są obecne w ciałach, tj. ponad duszami racjonalnymi, bez wątpienia są liczne umysły oddzielone od ciała. Jak właściwością czystego intelektu jest życie w oddzieleniu od ciała, tak naturą czystego zmysłu jest pozostawanie w ciele. Zatem duch ${ }^{2}$, w którym wraz z życiem jest jedynie zmysłowość, tylko przebywa w ciele, jak się wydaje; natomiast duch, w którym jest jedynie intelekt, żyje tylko poza ciałem. Jednakże, gdzie intelekt łączy się ze zmysłami, co ma

1 Ficino utożsamia duszę z życiem, podkreślając, że jest dla niej konstytutywne; nie można pomyśleć duszy jako takiej, która jest życia pozbawiona. Por. np. M. Ficino, Theologia Platonica, vol. II, V.15, 100.

2 W oryginale 'spiritus'; Ficino używa tego określenia w odniesieniu do wszystkich bytów, które uznaje za niecielesne. 
miejsce u człowieka, duch tego rodzaju cechuje się taką naturą, że może żyć i w ciele, i poza ciałem. Ponieważ zaś intelekt w tym [duchu] stanowi określoną część duszy zawierającą także inne części, jest labilny i w pewnym duchowym ruchu przemieszcza się od jednej do drugiej rzeczy, myśląc. Z tego powodu konieczne jest, aby ponad nim był umysł doskonalszy, który ani nie ogranicza się do zdolności [charakterystycznych dla] duszy [ludzkiej], ani nie miesza się z częściami niższymi, ani [też] swoich działań nie udaremnia z powodu czasu, ale pozostaje zupełny w samym sobie, czysty i jasny, a swojego działania nie wykonuje, miotając się [w ciągłym rozważaniu dyskursywnym], ale pozostając [w stanie kontemplacji].

\section{Ponad umysłem w duszy istnieje umysł sam w sobie, a ponad nim jest Bóg}

Potwierdza to takie platońskie uzasadnienie: jeśli dusza co do swojej formy $\mathrm{i}$ istoty byłaby umysłem, z pewnością cała dusza w pełni byłaby umysłem, umysłem - jak mówię - czystym; i dowolna dusza wydawałaby się obdarzona [jedynie] umysłem. Skoro zaiste rzecz ma się inaczej, jasne jest, że dusza nie posiada umysłu zgodnie ze swoją właściwą jej główną formą, ale zgodnie z pewnym uczestnictwem. I jak ponad umysłami dusz, które są określane jako takie ze względu na uczestnictwo, rzeczywiście są liczne umysły zgodne [z właściwą im] formą, tj. aniołowie, tak ponad umysłami zgodnymi [z właściwą im] formą, jest jeden umysł będący swoją przyczyną i mocą sprawczą, tj. Bóg.

Wiele jest ludzkich umysłów, wiele anielskich, boski - jedyny

Na podstawie tego, że dusze rozumne są liczne, i tego, że w tym samym momencie w umysłach różnych ludzi pojawiają się zupełnie przeciwne sobie poglądy, nastroje, postawy, oczywiste jest, że jest wiele umysłów [będących 
umysłami] dzięki uczestnictwu. Wskazaliśmy powyżej, że liczne są również umysły zgodne [z odpowiednią dla nich] formą, kiedy powiedzieliśmy, że stan samego umysłu jest [właściwszy, gdy] żyje bez zmysłów i ciała niż [kiedy jest złączony] z nimi. To, że ponad wszystkimi umysłami, które mają taką formę, jest jedyny umysł stanowiący swoją przyczynę, dowodzimy z tego powodu, że skoro duchowa wielość jednostkowych umysłów jest bardziej uporządkowana i zjednoczona niż wielość ciał, konieczne jest, aby zjednoczenie tego rodzaju pochodziło od jakiejś jednej przyczyny. Różne rzeczy bowiem, czy to cielesne, czy to niecielesne, nie mogą, z tego samego powodu, z którego są różne, być zgodne co do działania, porządku czy celu. Jednakże zwiera się w nich coś wspólnego i to samo, co nazywa się wspólnym dla wszystkich rzeczy, nie pochodzi od żadnej z tych rzeczy, które w sposób właściwy są ujęte w [określonym] porządku. Wówczas bowiem [to, co wspólne], byłoby właściwe jej jedynie lub jakimś należącym do niej rzeczom, a nie [byłoby] wspólne na równi każdej rzeczy. I ta wspólna jakość nie pochodzi od wszystkich rzeczy, z właściwej im i różnorodnej natury; te rzeczy bowiem, które są różne, jak mówimy, na ile są różne, nie rodzą jedności. Czy można jednak twierdzić, że natura, która dla wszystkich rzeczy jest wspólna, istnieje sama z siebie? W żadnym razie. Czymś wyższym jest zaistnienie z samego siebie niż trwanie w samym sobie. Jeśli bowiem natura tego rodzaju trwa nie w sobie, ale w mrowiu [innych rzeczy], z pewnością nie może zaistnieć z samej siebie. Zatem ze względu na to, że pewna jedność trwa w sobie ponad wszelką ilością, jedność owa przekracza każdą rzecz. I ponieważ ta znakomita jedność nie jest właściwa żadnej rzeczy, przeto, jak jedność numeryczna każdorazowo jest obecna dla każdej liczby, i [jak] punkt dla linii, tak ona sama, pozostając niepodzielna, jest także każdorazowo jednakowo obecna dla rzeczy duchowych i cielesnych, i tak samo łączy wzajemnie wszelkie rzeczy. $Z$ tego powodu rzeczy te zwracają się ku czemuś jednemu z pewną wzajemną zgodnością, ponieważ pochodzą od czegoś jednego. Jak zatem wszystkie ciała na świecie sprowadzają się do tego jednego i najwyższego, które zawiera w sobie i porusza wszelkie [inne ciała], tak wszystkie duchy [sprowadzają się] do jednego i najwyższego ducha, który obejmuje [sobą] wszystko i poprzez duchy jemu podległe ożywia oraz porusza ciała. 


\section{Rzeczy nie mieszają się [jak] w kole [wzajemnych zależności], nie sprowadzają się do wielu takich samych zasad ani nie postępują ku górze bez końca}

Tu, jak się wydaje, wyklucza się trzy błędy. Pierwszy jest tych, którzy uważają, że wszystko, jak w kole, zależy od siebie nawzajem, jak kiedy to zależy od owego, i tak owo $\mathrm{z}$ kolei od tego. $\mathrm{W}$ takim razie koniecznie to samo byłoby uznawane za to samo i przyczyna za skutek, i to, co wcześniejsze, za to, co późniejsze, i to, co wyższe, za to, co niższe. Drugi błąd wprowadza wielość zasad, [wówczas] bowiem byłaby pewna liczba zasad złożona ze wspólnej natury i [różnych] własności. Zatem żadna $\mathrm{z}$ nich nie byłaby rzeczywiście zasadą, ponieważ żadna nie byłaby prosta, a rzeczy jednostkowe pochodzą z wyższej jedności, która wszystko łączy. Trzeci błąd [popełniają ci], którzy [sądzą], iż rzeczy zawsze kierują się ku górze bez końca, od jednej zasady do innej. Wydaje się, że oni, podczas gdy z dużym zainteresowaniem starają się ująć niezliczone zasady, skoro nigdy nie znajdują pierwszej, w ogóle żadnej zasady nie uchwytują. Bez wątpienia powinni byli pomyśleć, że to, co zależy od czegoś innego, z natury jest labilne i całkowicie chwiejne, o ile nie jest podtrzymywane przez coś, co nie zależy od czegoś innego. Stąd, jeśli każda rzecz zależy od jakiejś innej bez końca, wszystkie są całkowicie chwiejne. Podobnie, jeśli to, co niestałe, tkwi w tym, co niestałe, i nigdzie nie ma czegoś stałego, co mogłoby utrzymać to, co niestałe, nie będzie w rzeczach żadnego [stałego] stanu, porządku, cykliczności, trwałości, przywrócenia [do stanu pierwotnego]. Nie będzie [wówczas] żadnej rzeczy znakomitszej od innej, ponieważ gdzie nie ma tego, co najwyższe, tam jedne nie bardziej niż inne mogą zbliżyć się do tego, co najwyższe. Doprawdy jasno widzimy, że jedne [byty] w naturze czynią coś, [tj. są aktywne], inne są wytwarzane, te pierwsze bez wątpienia przewyższają [pozostałe] pod względem godności, te drugie podążają [za pierwszymi w porządku rzeczy]. Ponadto [obserwujemy też], że wprowadzanie wielości i rozległości przyczyn wprowadza liczność i obfitość w zakresie skutków. Zatem jeśli następuje wznoszenie się bez kresu od przyczyn do przyczyn [i] podobnie następuje zniżanie się bez kresu do skutków od skutków, nic nie stanowi krańca, lecz wszystko jest pośrednie, wszystko 
nieskończone. Jeśli rzeczywiście jakaś rzecz uzyska moce od niezliczonych ją poprzedzających i będzie mogła dać moce niezliczonym następnym, niezliczone będą nieskończone, co jest absurdem. Dowolna rzecz będzie się przedstawiała tak samo jak [inna] dowolna rzecz, co uznaje się za nie mniej absurdalne. Nigdzie nie znajdzie się najniższego ciała, jakim jest ziemia, nigdzie najniższej materii, która jest jedyną czystą możnością przyjmowania form. Jeśli nie ma najwyższego ducha, jeśli nie ma najwyższej formy, czystego aktu i źródła form, nigdy nie zaczną realizować się żadne skutki, ponieważ pośrednie przyczyny nigdy nie zaczną wytwarzać [tych skutków i] nie zaczną działać, zanim nie zostaną wprowadzone w ruch przez wszystkie wyższe [przyczyny], co nigdy nie nastąpi, jeśli początek ruchu byłby oczekiwany od niezliczonych [przyczyn] i przez niezmierzoną odległość. Nie będzie żadnej nauki o jakkimkolwiek skutku, ponieważ nie nastąpiłoby żadne rozumienie niezliczonych przyczyn. Co więcej? Poszczególne ruchy w sprawach ludzkich i w przyrodzie są wobec tego ukierunkowane na określone cele, ponieważ rządzi nimi określona zasada; dlatego gdyby nie były zarządzane, nigdy nie zostałyby tam skierowane. Ponieważ zaś ruch wszechświata jest bardziej uporządkowany niż poszczególne ruchy, które odnoszą się do jego porządku, to intensywniej skierowuje się ku określonemu celowi, mianowicie ku powszechnemu dobru i pięknu. Konieczne jest wychodzenie od jednej i określonej zasady, tj. od dobra samego i najwyższego piękna.

\section{Prawda jest ponad umysłem}

Doprawdy, abyśmy przypadkiem sami także o niemal nieskończoną odległość nie odstąpili od założenia naszej dyskusji, kiedy usiłujemy przeciąć nieskończony bieg, jeśli można, powróćmy do umysłu. Czym jest oko w ciele i wzrok w oku, tym jest intelekt w duszy. Ponownie, czym jest Słońce w odniesieniu do wzroku, tym jest światło prawdy w odniesieniu do umysłu. Czym innym jest światło Słońca niż oko, podobnie czym innym jest sama prawda niż intelekt. W przeciwnym razie każdy umysł byłby całkowicie prawdomówny i dowolna rzecz byłaby częścią prawdy i podobnie byłaby częścią pojmowania. Twoje oko jest częścią czegoś innego, tj. ciała, i nie widzi bezpośrednio 
jasno wszystkiego ani wszystkich swoich [przedmiotów postrzegania] jednocześnie. Jeśli całe twoje ciało mogłoby działać niczym jedno oko, widziałoby w jedności wszystko równocześnie. Ale jednak oko i światło nie są tym samym. Podobnie twój umysł jest częścią duszy, stąd nie pojmuje wszystkiego ani jasno, ani momentalnie. Jeśli cała twoja dusza rozumna (animus) okazałaby się jednym intelektem ${ }^{3}$, to dusza stałaby się aniołem i jasno postrzegałaby wszystkie rzeczy, nie uchwytywałaby w większym stopniu raz tego, raz tamtego, podczas zachodzącego w czasie rozumowania dyskursywnego, ale równocześnie jasno ujmowałaby wszystkie rzeczy. Niemniej jednak czym innym będzie sama prawda, czym innym sam umysł, który nie jest niczym innym niż duchowym okiem zdolnym do poznawania za pomocą intelektu i woli samego światła prawdy i ciepła dobra.

\section{Prawda i dobro są tym samym}

Wydaje się, że należy zbadać, czy prawda sama i dobro [samo] są jednym i tym samym. Pomijamy to, co dialektyczne związki [tu] chytrze wynajdują (machinentur). Jeśli w porządku rzeczy jest fałsz i zło, i bycie fałszywym oraz złym w rzeczywistości nie różni się między sobą, wynika $\mathrm{z}$ tego, że w tym samym porządku prawda i dobro oraz bycie prawdziwym i bycie dobrym niewątpliwie się nie różni. $Z$ tego powodu ponad porządkiem wszystkich rzeczy prawda i dobro są substancjalnie tym samym, zwłaszcza dlatego, że na ile poszerza się władza prawdy, na tyle poszerza się władza dobra, i odwrotnie. Cokolwiek bowiem należy do prawdy, to samo jest odnajdywane jako uczestniczące w dobru, i odwrotnie. To samo jednak, co nazywane jest prawdą i dobrem, przewyższa dowolny umysł, ponieważ umysł znajduje spoczynek [tj. koniec aktywności] nie w swojej własnej naturze, ale w posiadaniu prawdy i dobra. Ponadto ślady prawdy i dobra szerzej się rozprzestrzeniają niż [ślady] inteligencji. Gdzie bowiem nie ujawnia się żaden wytwór inteligencji, tam jednak wydaje się, że ukrywa się nieco tego, co należy do sfery prawdziwego

3 Ficino często stosuje termin 'animus' dla określenia duszy rozumnej i 'anima' dla określenia całej duszy (wraz z niższymi władzami). 
i dobrego. Co zatem powiemy? Bóg rozmieszcza wszystko na wzór swojej sztuki w jakimś właściwym i czystym gatunku, następnie zgodnie ze wzorem swej hojności łaskawie przydziela wszystkiemu porządek i pewną użyteczność do czegoś: w jednym akcie czyni wszystkie rzeczy prawdziwymi, w drugim dobrymi. Ponownie, kiedy Bóg oświetla inteligencję, jest prawdą, kiedy ogrzewa wolę, nazywany jest dobrem. Tam inteligencja jest oświetlona i wzrasta, tu wola jest łagodnie pozyskiwana i nasycana.

\section{Bóg przewyższa umysł o nieskończoną odległość}

Zmierzmy ponadto, jeśli da się zmierzyć, skoro Bóg przewyższa umysł, o jak wielką odległość go przewyższa. Ach, cóż za bezmierną głupotą jest chęć zmierzenia tego, co bezmierne! O przynajmniej tak znaczą przestrzeń godności na wysokościach jest odległy od umysłu, na jaką rozciąga się dyskurs rozumu, kiedy stopniowo ponad siebie przebiega od tego, co jaśniejsze, ku temu, co [jeszcze] jaśniejsze, i [na jaką rozciąga się pragnienie] woli, kiedy dąży od tego, co lepsze, ku temu, co [jeszcze] lepsze. Dotąd jest to jasne, dokąd nie znajdujemy czegoś pod każdym względem bezmiernego, co poprzez swoją nieskończoność w pewien sposób kładzie kres nieskończonemu postępowi.

\section{Bóg jest pewnością samą i radością samą}

Chociaż wydaje się krańcowo niedorzeczne chcieć umysłem pojąć to, co w sposób nieprzezwyciężalny przekracza umysł i bodziec dla umysłu, czyli wolę, w żadnym razie nie jest jednak nierozumne przynajmniej chcieć być w pełni przez to pojmowanym (comprehendi). Być może bowiem pojmowanie niepojmowalnego nie jest niczym innym niż byciem przez to szczęśliwie pojętym. Cóż zatem? Czy chcemy być pojmowani w sposób najbardziej oczywisty przez najwyższą i niestworzoną formę, która aż do tego momentu ogarnia nas skrycie; tj. tak pojmowani, że ona sama nie jest przed nami ukryta 
w najmniejszym stopniu? Zrozummy, na ile możemy, że wśród rodzaju form stworzonych są najwyższe, a rzeczywiście najwyższe wśród nich są te, które mogą się bezpośrednio zwrócić ku najwyższej i niestworzonej formie ze względu na to, że bezpośrednio od niej pochodzą. Wydaje się, że taki jest wszelki gatunek umysłu, zważywszy, że codziennie wszystkie one [tj. umysły] mogą szukać najwyższej boskości, rozważać ją i otaczać czcią, nie tylko w innych rzeczach, ale także, po odrzuceniu wszystkich pozostałych, w pewnej własnej - że tak powiem - doskonałości. Najwyższe więc we wszechświecie, po najwyższej zasadzie wszechświata, są umysły jako zwieciadła tego, co najwyższe. Uchwyćmy [teraz] to, co jest najwyższe w umyśle, czyli sam intelekt $\mathrm{i}$ wolę, potem to, co najwyższe $\mathrm{w}$ intelekcie i woli: w pierwszym $\mathrm{z}$ wymienionych to [najdoskonalsze] pojmowanie (intellegere), w drugim zaś chcenie. Dalej, co jest najwyższe w pojmowaniu, następnie - co w chceniu. $\mathrm{W}$ tamtym doprawdy najwyższa jasność, tj. najdokładniejsza pewność całej prawdy, w tym najpełniejsza radość, tj. pełne i pewne rozkoszowanie się wszystkimi dobrami. Nic ponadto nie możemy wymyślić ani [niczego sobie] życzyć. Czym zatem jest Bóg? Z pewnością, jak ukazuje się to w umyśle, Jego zwierciadle, Bóg jest najjaśniejszą i najpewniejszą prawdą, źródłem wszelkich prawd. [Jest] najprawdziwszą jasnością spośród jasności, dalej, nieskończonym dobrem, które kiedy raduje się samym sobą, raduje się z niezliczonych dóbr; radością [będącą] samą z siebie bezgranicznym dobrem, które z siebie samego sprawia, że inne rzeczy są dobre i można się nimi cieszyć.

\section{Pewność sama lub jasność jest tym samym, co sama radość}

Kiedy mówimy, że Bóg jest jasnością lub radością, nie stwierdzamy, że [jest] jasnością w intelekcie lub radością w woli, lecz w nich samych [czyli radością samą w sobie i jasnością samą w sobie]. Nie chcemy, aby jasność odróżniała się od radości tu, gdzie prawda nie odróżnia się od dobra. Jest zatem radosną jasnością i jasną radością; jasnością, powtarzam, radującą się nie radością z jakiejś innej rzeczy, ale pochodzącą z samej siebie; radością jasną nie inną jasnością, ale pochodzącą z samej siebie. 


\section{Jak światło nie potrzebuje oka, tak prawda nie potrzebuje umysłu}

Czym innym jest oko, czym innym promień tkwiący w oku, [jeszcze] czym innym najbardziej rozległe światło Słońca. Ten promień jest jasnością i [znajduje] się w oku, światło to zaś jest powszechną jasnością, jasnością niepotrzebującą oka, które jest uformowane do jej postrzegania. Podobnie czym innym jest umysł, czym innym swoista dla niego jasność, tj. promień umieszczony w nim od początku; czym innym [jeszcze] Bóg, jasność przwyższająca wszelką jasność, jasność niepotrzebująca umysłu, który wydaje się stworzony, aby ją samą dostrzegać; [Bóg] radość wszelkich radości, które są odczuwane przez jakąś wolę, radość niepotrzebująca woli doznającej radości, chociaż każda wola się nią raduje.

\section{Dla najwyższej pewności nic nie jest niepewne}

Jeśli światło Słońca byłoby nie tylko przyczyną widzenia i samego bycia widzialnym, ale także przyczyną przyczyn, i samo widzenie byłoby najdoskonalszym i najbliższym skutkiem Słońca, ponieważ doskonałość nie może wywodzić się od niedoboru, a raczej potrzeba doskonałego widzenia do wytworzenia czegoś niedoskonałego, z pewnością wszystko, co wydaje się dobre i najbardziej pożądane w widzeniu, byłoby o wiele doskonalsze w świetle. Najlepsze i najbardziej pożądane dla oka jest to, że samo światło się nie ukrywa i nie stoi [mu] na przeszkodzie, gdy jest widoczne, odwrotnie - silnie cieszy (oblectet). Światło natomiast, jeśli nie miałoby oka, to jednak pewnym swoim sposobem, tzn. jakby szlachetniejszym widzeniem, jasno widziałoby siebie i ujmowało wszystkie kolory w sobie [jako] źródle kolorów. Widziałoby także siebie, będąc tym, co widzą wszystkie oczy, i widziałoby także, że wszędzie wszystko to, co widzi, [widzi] przez nie samo. Pomijam teraz, że platonicy sądzą, że światło widzi wszystko. Bóg zaś jest całościową i bezpośrednią przyczyną umysłu, a umysł jest najwyższym dziełem Boga. Cokolwiek najlepszego umysł usilnie powinien pragnąć, to wszystko Bóg już posiada 
w sposób doskonalszy, niż da się pomyśleć. Cóż jest bardziej pożądanego dla intelektu niż pewność wszystkich prawd? Cóż [bardziej pożądanego] dla woli niż radość ze wszystkich dóbr? Nie wystarczyłoby umysłowi posiadanie przezeń prawdy (zapytaj go), jeśli ta, którą posiada, byłaby przed nim ukryta. Nie wystarczyłoby całe dobro, jeśli nie byłoby dlań przyjemne i nie cieszyłby się nim całym. Boska jasność zatem, chciaż intelekt nie korzysta z niej właściwie, w najmniejszym stopniu się nie ukrywa. I nigdzie nic się przed nią nie ukrywa, skoro poprzez nią wszystko i wszędzie staje się oczywiste. Cóż zatem mogłoby być dla czegoś pewne, skoro nie byłoby pewne dla pewności samej, dla której wszystko jest pewne?

\section{Gdzie jest główny cel umysłów, tam jest ich początek}

Powtórzmy jednak w ten sposób to, co powiedziane wyżej: dowolny skutek z natury dąży do [swojej] przyczyny, jako że gdzie jest wytworzony, tam także uzyskuje doskonałość. Dąży właściwie do przyczyny najbliższej, jeśli jest ona taka, że skupia w sobie zadania wszystkich oldegłych przyczyn, i poprzez jej formę [podąża] też do odległej [przyczyny]. Właściwą i oddzieloną formę otrzymuje bowiem raczej od przyczyny najbliższej niż odległej, wobec tego także w tej najbliższej, o której mówiłem, miał swój początek, jak również właściwy cel. Podobnie ogień ma swój naturalny kres raczej we wklęsłości [sfery] Księżyca niż Słońca czy Marsa, a powietrze we wklęsłości [sfery] ognia, a nie [sfery] Wenus lub Jowisza. Skoro więc każdy umysł, mając naturę [rzeczy] za przewodnika, umieszcza [swój] jedynie właściwy i najważniejszy cel albo z najwyższą radością w samej najwyższej pewności wszystkiego, albo z najwyższą pewnością w najwyższej radości wszystkiego, jako w najbliższej przyczynie, któż nie widziałby, że sam Bóg, będący przyczyną umysłów, jest że tak powiem - najwyższą pewnością i największą radością? Pewnością, mówię, nie czegoś, w czymś lub co do czegoś, ale siebie samej, w sobie samej i co do siebie samej; w przeciwnym razie [pewność ta] nie byłaby czysta i prosta ani też najwyższa. Skoro zatem z żadnej strony nie otrzymuje żadnego krańca ani miary, musi pozostawać niezmierzona. $Z$ tego powodu zupełnie nie przyjmuje niczego niepewnego. Zatem nic niepewnego dla tej pewności nigdy nie 
może czy to być, czy tkwić w niej lub poza nią. Jest ponad wszystkim, każdą rzecz przekraczając. I w swym byciu oraz działaniu nie zależy od czegoś innego, ale inne rzeczy w nich obu zależą [od niej]. Skoro w niej nie jest niczym innym bycie sobą samą i bycie pewną, a właściwie bycie pewnością, bez wątpienia dopóki przynależy do samej siebie, podobnie jest pewna samej siebie, dokładniej zaś mówiąc, [jest] pewnością. I dopóki jest pewna samej siebie, a obejmuje wszystko [swą] niezwykłą mocą, bez wątpienia jest pewna wszystkiego, a właściwie jest pewnością wszystkiego. Stąd światło, w którym wszystko jest widziane, nie jest niczym innym niż pewnym duchowym poszerzeniem czystej i skutecznej formy. Gdzie zatem czystość i skuteczność formy nie jest ograniczona, tam rozrasta się nieskończone światło i stamtąd emanuje całkowicie niezmierzona świetlistość. Z pewnością to, co znajduje się w ciałach, to wyrazistość (perspicuitas), a to, co znajduje się w bytach duchowych, to przenikliwość (perspicacia). Dalej, co w przypadku ciał stanowi widzialne światło, to w bytach duchowych jest oglądem, stąd ciała, które bliżej przystępują do tego, co duchowe, łatwiej i obficiej świecą; i odwrotnie: te, które świecą samodzielnie, rozprzestrzeniają duchową jakość. Wobec tego w najwyższym bycie duchowym żyje najwyższe światło i widzenie. W nim jasność i widzenie są tym samym. Nie mówię, że Bóg jest jakąś zdolnością widzenia, która wymaga aktu widzenia, ani też znowu nie nazywam Go tym, co określa się jako widzenie, ani staraniem się zobaczenia czegoś innego, ani [jakimś] złożeniem, ale poprzez właściwe określenie aktu nazywam Boga widzeniem istniejącym przez siebie samo, widzącym nie poprzez [inną] jasność niż [poprzez] samą siebie. Dlaczego powiedziałem, że jest „widzeniem”? Któż bowiem powiedziałby niewłaściwie: „widzenie widzi”, a „wiedza wie”? Nie jest bowiem tak, że wiedza jest ignorancją czy widzenie ślepotą. Podobnie, nie można właściwie powiedzieć o samym widzeniu, że widzi [ogólnie] cokolwiek ani, dalej, że gdzieś jest coś, co jednak nie jest dla niego [tj. widzenia] wyraźnie widoczne i jasne. Jak bowiem dla tego lub owego widzenia to lub owo jest jasne [i wyraźne], tak dla samego najwyższego i nieskończonego widzenia wszystko jest jasne i wyraźne. Tam też jest najbardziej obfita radość, gdzie rozbłyskuje najwyższa jasność, będąca źródłem radości duchowej, ściślej biorąc, tym samym jest tu jasność i radość. Czy to bowiem w oku, które w ciele wydaje się najbardziej duchowe, czy to w samym duchu, niczym innym nie jest radość niż albo samą jasnością, albo odpowiadającym [jej] 
oświeceniem (illuminatio). Któż ma wątpliwości, że tam panuje radość, gdzie jest wszelkie dobro? Przecież najbardziej pragnie się radości jako najlepszej ze wszystkiego i jest ona zarówno blaskiem i łaską wypromieniowującego się dobra samego, jak i pewnym poszerzeniem wypromieniowanej wokół dobra mocy.

\section{Bóg jest najradośniejszą jasnością i najjaśniejszą radością}

Kiedy natomiast chcemy mówić najsłuszniej, nie nazywamy Boga intelektem w sposób właściwy, nie potrzebuje [bowiem] aktu pojmowania, ani też nie [nazywamy Go] samą inteligencją, nie pozostaje bowiem w jednym intelekcie i nie jest napełniany jakimś innym światłem. Raczej [powinien być nazywany] cudownie radosną jasnością samą i najjaśniejszą radością, którą tak otaczają wszyskie intelekty, jak wszystkie gwiazdy [otaczają] Słońce; jasnością - mówię - widzącą wszystko promieniami swojej pewności i sprawiającą, że wszystkie rzeczy widzą i są widziane; [jest jasnością] stwarzającą ponadto pojedyncze rzeczy płomieniami swojej radości, [stwarzającą] jakby z przyjemności bycia stwórczynią wszystkiego, stworzone [byty zaś] także podtrzymuje [w ich istnieniu] i czyniąc to, na nowo ożywia [je], ożywione porusza poprzez [ich] zmysł, poruszone przyciąga [poprzez ich] rozum, [tak] uzyskane [z kolei] zatrzymuje za pomocą [ich] umysłu, zatrzymane ostatecznie całkowicie wypełnia swoją prawdą i dobrem.

\section{Bóg stwarza i porusza rzeczy raczej wolą niż intelektem*}

Cieszy jednak swoiste wzniesienie się, poprzez jakieś podobieństwo, od tego, co najpiękniejsze w ciałach, do najlepszego ducha. Słońe, [cielesna]

* W oryginale: „Deus volendo res facit et movet, potius aum intelligendo”, tj. uwzględniając najczęstszy sposób tłumaczenia gerundium: „Bóg stwarza i porusza rzeczy raczej chceniem niż pojmowaniem”. 
podobizna Boga, tym samym światłem w sobie rozbłyska i tym sposobem goreje, również tym samym promieniem oświetla i ogrzewa poszczególne rzeczy, jednakże wytwarza i porusza rzeczy, ogrzewając raczej niż oświetlając. Podobnie sam Bóg, wzorzec Słońca, tą samą jasnością wyjaśnia [podkreślenie moje - J.P.] dla siebie samego, na swój sposób pojmując, i sam raduje się sobą poprzez chcenie [tj. wolę]. Poza tym poprzez promienie tej samej jasności, jak wyrażamy to niekiedy w ludzkim języku, pojmuje wszystko i chce wszystkiego. Jednakże stwarza nie tyle pojmowaniem, ile chceniem. Stąd wydaje się, że wszystkim zwierzętom i rzeczom naturalnym udzielone jest to, że z pewnym pożądaniem, zgodnie z naturą każdego $\mathrm{z}$ nich, a także z przyjemnością dla siebie, tworzą to, co im podobne. Powinniśmy natomiast pamiętać, że Bóg, pojmując siebie, pojmuje inne rzeczy, będące pewnymi promieniami samej inteligencji, a pragnąc siebie, tj. ciesząc się sobą samym, pragnie innych rzeczy i raduje się nimi, będącymi pewnymi afektami Jego [wolitywnego] działania. Działanie tego rodzaju, mianowicie wynikające $\mathrm{z}$ woli, ponieważ jest najdoskonalsze, jest zgodne z Bogiem jako najdoskonalszym spośród czynników działających. To, co działa zgodnie z wolną wolą, działa doskonalej niż to, co jest skłaniane do działania z impulsu natury, [czyli] z konieczności. Z pewnością najszczęśliwsze jest działanie, w którym wykonawca jest panem swoich czynności, tak że sam wyznacza cel, metodę i miarę swojego działania, a także ustanawia dla swoich dzieł właściwy cel oraz określone sposoby [ich funkcjonowania]. Bez wątpienia, jeśli Bóg poprzez naturalną jakość tak czyniłby [wszystko] jak ogień ociepla gorącem, byłby najbardziej złożony spośród wszystkiego, zważywszy, że stwarzałby niezliczone rzeczy ze swych naturalnych, oddzielonych od siebie form; szczególnie rzecz dotyczy tego, co może powstać tylko poprzez stworzenie, mianowicie samej materii i formy (czy to oddzielonej od materii, czy to oddzielalnej). Co więcej, nie oddzielałby kolejno rzeczy jednostkowych, ale wszystkie jednocześnie wylewał (effundet), a właściwie zlewał [tj. mieszał] (confundet). Ponadto skoro jest aktem bezgranicznym, momentalnie wywołuje określony stan (coget) wszystkiego i w jednej chwili poruszy sfery świata. We wszechświecie nie pozostawi nic przygodnego, zniesie wolność rozważań. Doprawdy, skoro wszystko wykonuje zgodnie $\mathrm{z}$ wolą, z tego powodu wszystko czyni i porusza, i zatrzymuje $\mathrm{w}$ takim stopniu, $\mathrm{w}$ jakim chce. Nietrudno pojmuje 
wszystko ten, w kim tym samym jest pojmować i być. Bez trudu stwarza rzeczy jednostkowe i troszczy się o nie ten, w kim tym samym jest czynienie czegoś i chcenie czynienia. Pojmuje wszystkie rzeczy prawdziwe, kiedy pojmuje siebie samego, [będącego] wszelką prawdą. Ponadto chce wszystkich dobrych rzeczy, kiedy chce siebie samego, będącego wszelkim dobrem. Inna jest zdolność działania boskiej inteligencji i woli, inna ludzkiej. Człowiek naprawdę pojmuje zasady rzeczy, kiedy pojmuje je przede wszystkim takimi, jakimi są. One natomiast są prawdziwe dlatego, że są takie, jakimi pojmuje je Bóg będący samą prawdą, poprzez którą wszystkie rzeczy są prawdziwe i wszędzie prawdziwie są pojmowane. Ludzka wola pragnie poszczególnych rzeczy, ponieważ są dobre. Te stworzone rzeczy [zaś] są dobre dlatego, że ich samych pragnie Bóg będący dobrem samym, poprzez które [to dobro] i rzeczy te są dobre, i my pragniemy poszczególnego dobra.

\section{Bóg ma pieczę nad wszystkimi rzeczami, szczególnie zaś} nad umysłami, ponieważ są stworzone bezpośrednio z Niego

Dlatego jasne jest, że pierwsza przyczyna z łaskawości swej woli sprawuje pieczę nad wszystkim, ponieważ w najwyższym stopniu wszystko do niej należy. Bez wątpienia, skoro jest główną przyczyną, na tyle jest przyczyną zachowania [rzeczy] i doskonalenia, na ile [ich] stwarzania. Najwyższa opatrzność szczególnie dotyczy najwyższego dobra, jest ona bowiem rozpowszechnianiem i zachowaniem tego, co dobre. Wiadomo ponadto, że dalsze przyczyny, skoro od pierwszej otrzymują urodzajność i [określoną] skłonność, nabywają od niej dbałość opatrzności nad swoimi [skutkami]. Gdyby ktoś rzeczywiście zanegował, że świat jest rządzony najzręczniejszym rozumem i najżyczliwszą wolą, wydaje mi się, że nie rozważył był rozumnego i najpiękniejszego porządku rzeczy w nich samych, względem siebie i w odniesieniu do całości, ani zadziwiającego dopasowania poszczególnych rzeczy wszędzie im służącego i wzajemnego ich użytku. Bez wątpienia wygodne mieszkanie jako cel skłania budowniczego niczym przyczynę sprawczą, aby obmyślił jakąś formę domu, ze względu na którą następnie wybierze materiał. Tu cel porusza czynnik działający, czynnik działający formę, forma materię. To samo ma miejsce 
w postanowieniach politycznych i wojennych. Stąd cel jest przyczyną przyczyn i z tego powodu poprzedza wszystkie przyczyny. Wobec tego wszystkie rzeczy naturalne są ustanowione dla jakiegoś określonego celu: wydaje się bowiem, że poszczególne [rzeczy] nade wszystko prowadzą do jakichś poszczególnych pożytków. Przykładowo, wić winorośli, nazywana czepem, wyrasta po to, by przywiązać winorośl do najbliższego drzewka. Ten akt wiązania jest przyczyną powstania czepu. Ponieważ zaś to, co nie istnieje w żaden sposób, nie może być przyczyną zaistnienia jakiegokolwiek skutku ani poruszać wszystkich przyczyn, to akt tego rodzaju istniał przed wicią i przed wszystkimi pozostałymi przyczynami winorośli. W przypadku ciał [w sposób widoczny] istnieje jako ostatni. Istniał zatem w pewnej niecielesnej naturze kierującej ciałami długo przed [zaistnieniem] winorośli. Z pewnością twórczyni-natura winorośli dzięki aktowi tego rodzaju poprzez swoją formę ukształtowała formę wici w takiej materii. Czy jednak akt tego rodzaju był wcześniej w owej naturze zgodnie ze sposobem [funkcjonowania] natury, czy zgodnie z postanowieniem woli? Z pewnością zgodnie z jednym i drugim. Z tego natomiast wynika, że było to tym samym, co pewna forma czynnika działającego i wzór jego skutku, zgodny z tym [z kolei] był cel. Gdzie bowiem jest postanowienie twórczej (artificiosae) woli, tam jest umysł. Dlatego zatem boski umysł poprzedza wszystkie rzeczy cielesne, który w sposób intelektualny obejmuje formy wszystkiego, co cielesne, kierując poszczególne rzeczy do ich celów, a wreszcie wszystko razem do jednego [celu]. Spośród wszystkiego najbardziej Bóg troszczy się i miłuje nie tylko umysły anielskie, ale i ludzkie, jako jego najbliższe potomstwo. Ponieważ bowiem są jednostkowe i oddzielalne lub oddzielone od materii, nie mogą być utworzone z jakiejś poprzedzajacej [je] części lub materii, doprawdy z niczego, co jest nieskończenie odległe od bytu samego, to wydaje się, że konieczne jest [tu] działanie jedynej nieskończonej mocy.

\section{Wszystkie umysły są jednostkowe, oddzielalne od materii i wieczne}

To, że umysły są niepodzielne, oddzielone lub oddzielalne od materii, wynika stąd: ponieważ ujmują samą niepodzielną i całkowicie oddzieloną 
zasadę (rationem), dzięki której liczne rzeczy są niepodzielne i oddzielone, i [jako takie] poznawane, zasadę - mówię - właściwie [poznawaną] w tym, że jest niepodzielna [tj. jednostkowa] i oddzielona. W jaki sposób linie [średnice] mogą dotknąć niepodzielnego środka jedynie poprzez ich niepodzielny punkt, w taki my możemy dotknąć jednostkowej oddzielonej natury nie inaczej niż jednostkową oddzieloną władzą. Bóg troszczy się o te byty, którym podczas stwarzania przydziela tymczasowe istnienie, zapewniając im tymczasowe dobro. Jeśli zaś chodzi o te, którym ze swej niezrównanej hojności przyznaje wieczne istnienie, kieruje je ku dobremu istnieniu nie w czasie, ale w wieczności. Stąd tak kształtuje rzeczy w czasie, że chociaż nie są widziane jako dobre dla tych [bytów], które nie dostrzegają samej wieczności, to jednak są najlepsze dla [bytów wiecznych], nie jest bowiem ukryte dla nich, w jaki sposób czas służy wieczności. To natomiast, że umysłom przydzielił życie wieczne, pokażemy teraz krótko na podstawie samego pojęcia (ratio) i światła przy pomocy jasnego światła rozumu. Najpierw w odniesieniu do pojęcia (ratio) w ten sposób: jeśli istota (ratio) dowolnej rzeczy jest ukazywana we właściwej definicji jej gatunku, nie można przyjąć inaczej: ktokolwiek wątpi, że sama istota istot nie może się mieć inaczej, ten albo nie używa rozumu, albo nadużywa. Zatem najwyższa istota jest wieczna lub raczej jest wiecznością. Ona udziela się wszędzie wszystkim umysłom, aby gdziekolwiek im się podoba, zgodnie z wolą, mogły prowadzić rozważania. Co więcej, tak hojnie przydaje im pewną własność swojej wieczności, że dalece w ramach funkcji rozumu, tj. wnioskowania (ratiocinatione), uchwytują wieczne, na ile są wieczne, istoty rzeczy; a wieczność istoty i istota wieczności jest ujęta w jej definicji. W odniesieniu do światła [wskażemy] w ten sposób: ci nie wątpią, że bezmierne światło boskiego Słońca jest niewyczerpalne, którzy spostrzegają, że jego zacieniony obraz w Słońcu na niebie nigdy się nie wyczerpuje. Jeśli jednak w najwyższym i czystym akcie, bez względu na rodzaj działania, nie można znaleźć żadnej możliwości doznawania czy braku, to w najniższej możności nie ma żadnego aktu, a w całkowitym braku żadnej dyspozycji. Owo ponadniebne światło, wśród wszystkich umysłów myślących o tym, co ponadniebne, rozprasza się szeroko i zgodnie z poszczególną ich naturą, jakby wśród gwiazd. Doprawdy tak dalece zachowuje tę swoją niewyczerpalną własność, że poprzez nią wraz z pewnym światłem rozumu odróżnia się to, co nie może się wyczerpać, od tego, co może się wyczerpać; [i poprzez 
nią] wykazuje się w rozumowych rozważaniach, że to jest wyczerpywalne, a tamto niewyczerpywalne. Bez wątpienia owo światło udzielane jest zgodnie z [jego] niewyczerpalną własnością wszędzie tam, gdzie postrzega się podstawę niewyczerpalnej natury. Najwyższe źródło każdej natury i światła jest poszukiwane, kochane i czczone zgodnie z naturalnym pragnieniem.

Przekład i opracowanie naukowe:

Joanna Papiernik Uniwersytet Łódzki e-mail: joanna.papiernik@filozof.uni.lodz.pl ORCID: 0000-0002-6106-7132 